\title{
Correction to: Prognostic influence of prior chronic obstructive pulmonary disease in patients admitted for their first episode of acute heart failure
}

\author{
Karine Luz Londoño ${ }^{1} \cdot$ Francesc Formiga $^{2}$ (1) $\cdot$ David Chivite $^{2} \cdot$ Rafael Moreno-Gonzalez $^{2}$. \\ Margherita Migone De Amicis ${ }^{3} \cdot$ Xavier Corbella $^{2,4}$
}

Published online: 10 August 2018

(c) Società Italiana di Medicina Interna 2018

\section{Correction to: \\ Internal and Emergency Medicine (2018) 13:351-357 \\ https://doi.org/10.1007/s11739-018-1820-3}

In the original publication, the given name and family name of the fifth author Dr Margherita Migone De Amicis were incorrectly published. The correct given name and family name should read as 'Margherita' and 'Migone De Amicis', respectively.

The original article can be found online at https://doi.org/10.1007/ s11739-018-1820-3.

Francesc Formiga

fformiga@bellvitgehospital.cat

1 Médica Universidad Libre, Cali, Colombia

2 Geriatric Unit, Internal Medicine Department, Universitary Hospital Bellvitge-IDIBELL, L' Hospitalet de Llobregat, 08907 Barcelona, Spain

3 Scuola di Specializzazione in Medicina Interna, Università degli Studi di Milano, Milan, Italy

4 Faculty of Medicine and Health Sciences, Universitat Internacional de Catalunya, Barcelona, Spain 